\title{
Angiotropic B cell lymphoma
}

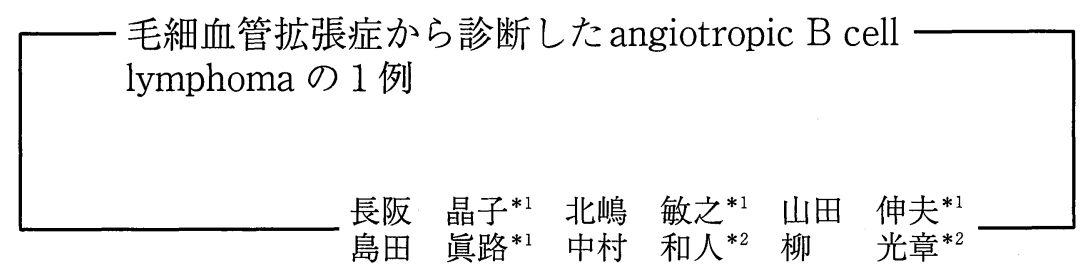

\footnotetext{
A case of Angiotropic B cell Lymphoma diagnosed by telangiectasia

Akiko NAGASAKA *1, Toshiyuki KITAJIMA*1, Nobuo YAMADA*1,

Shinji SHIMADA ${ }^{* 1}$, Kazuto NAKAMURA *2, Mitsuaki YANAGI*2

*1 Department of dermatology, Yamanashi Medical University

*2 Second Department of Internal Medicine, Yamanashi Medical University
}

Angiotropic lymphoma is a rare lymphoproliferative disease that affects vessels of all organs especially including the skin and central nervous system. We report a $67-$ year-old woman with angiotropic B cell lymphoma. Examination revealed striking telangiectasia on the skin of the chest and upper back as the major manifestation. She also had subacute slight disorientation.

Laboratory abnormalities showed elevated serum lactic dehydrogenase (LDH) $(2027 \mathrm{U} / l)$. A skin biopsy from the telangiectasia revealed the presence of many intravascular, large, atypical lymphoid cells with hyperchromatic nuclei.

On immunohistochemical analysis, neoplastic cells showed reactivity for CD20 but not CD45RO. These findings were consistent with angiotropic B cell lymphoma. By combination chemotherapy (VAB-COP: cyclophosphamide, adriamycin, etoposide, vincristin, bleomycin and prednisolone), the telangiectasia and disorientation were dramatically improved during the follow-up period. An early diagnosis and subsequent combination chemotherapy may contribute to longer survival in angiotropic lymphoma. [Skin Cancer (Japan) 2002 ; 17 :293-295]

Key words: Angiotropic lymphoma, Intravascular malignant lymphomatosis, $\mathrm{B}$ cell, telangiectasia, VAB-COP

はじめに

angiotropic lymphoma は腫瘍細胞が全身諸臓

${ }^{* 1}$ 山梨医科大学陂膚科

${ }^{* 2}$ 山梨医科大学第 2 内科
器の小血管腔内に選択的に増殖する特異な悪性 リンパ腫である。血管閉塞により多彩な臨床症 状を呈し, 腫瘤形成を伴わないため早期発見が 困難で予後不良な疾患である。今回, 前胸部の 毛細血管拡張を生検したことにより確定診断に 至った angiotropic lymphomaの1例を経験し たので報告する。 


\section{症例}

患 者: 67 歳, 女性

現病歴： 2001 年 5 月頃より全身倦总感·食欲 不振・体重減少 (2 2 月月で-10kg) および前胸部 の毛細血管拡張が出現したため, 7 月 10 日に精 査目的で当院内科を紹介受診となった。通院中 に末梢血中に $8 \%$ の異常リンパ球（WBC $12010 / \mathrm{ul}$ ）を指摘されたため悪性リンパ腫の疑 いで 8 月 20 日，内科入院となった。

既往歴：高血圧症，糖尿病

家族歴：特記すべきことなし。

初診時現症：体温 $37.9^{\circ} \mathrm{C}$, 表在リンパ節およ び肝・腎・脾は触知しない。意識レベルはJCS I-2で失見当識があり，神経学的異常所見はなし。 皮膚所見は頸部および前胸部・上背部にかけて 樹枝状の毛細血管拡張を認めた（図 1)。紅斑・ 皮下硬結・腫瘤は認めず，自覚症状はない。

入院時検査所見：WBC $9810 / \mu l$ (異型細胞な L), RBC 352 万 $/ \mu l$, Plt 35.8 万 $/ \mu l$, GOT $92 \uparrow$, GPT 13， $\gamma$-GTP 45 T.Bili 0.5 LDH $2027 \uparrow ，$ CRP $13.7 \uparrow$, 他は異常なし, 赤沈 $132 \mathrm{~mm} \uparrow, \mathrm{HBV}$ ・ $\mathrm{HCV}$ (一) $\mathrm{EBV} \cdot \mathrm{CMV}$ とも既感染パターン

$\mathrm{CT}$ 検査：有意なリンパ節腫大なし, 肝・脾腫 なし。

頭部 MRI：軽度の脳萎縮，明らかな占拠性病 変なし。

Ga シンチ：集積所見なし。

骨髄穿刺：異型リンパ球の浸潤なし，染色体 異常なし (46XY)，表面マーカー解析で異常な 細胞集団なし。

組織学的検査：悪性リンパ腫を疑い，全身検 査をするも異常所見を認めなかったため，前胸 部の毛細血管拡張より，生検した（図 2 )。組織 所見は真皮内の多数の小血管内にやや大型で異 型性のある好塩基性の腫崵細胞が充満して, 塞 栓を形成していた。血管外への腫瘍細胞の浸潤 はなかった。免疫染色では CD20 陽性, CD45RO 陰性であり，腫瘍細胞が B 細胞由来であると診

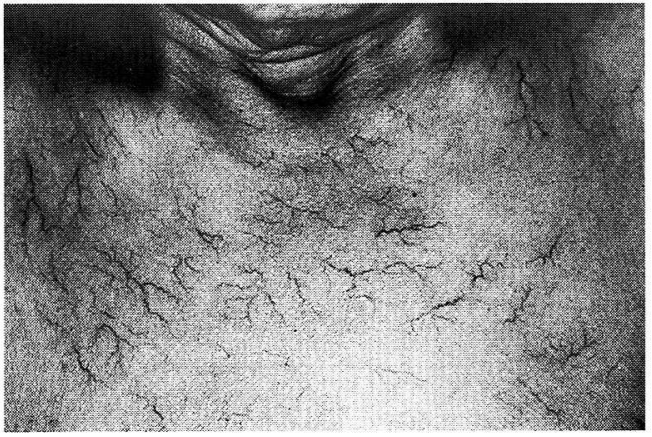

図 1.

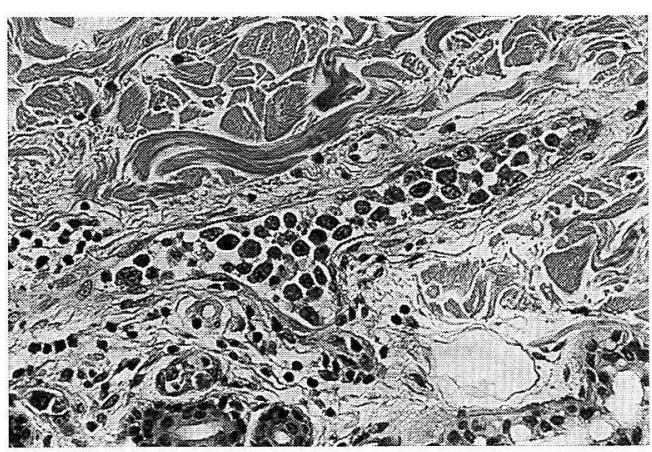

図 2 .

断した。

\section{治療と経過}

以上より angiotropic B cell lymphoma と診断 し, 悪性リンパ腫に準じてVABCOP-M 療法 (名 古屋リンパ腫研究会: VCR, ADR, BLM, CPA, ETP，PSL，MTX）を行った。全 7 コースを施 行し, 全身状態 ·毛細血管拡張 - 神経症状 · $\mathrm{CRP} \cdot \mathrm{LDH}$ はいずれも 1 コース目で著明に軽快 した。VABCOP-M 終了後, 8 カ月経過した現在 も再発は認めない。

\section{考察}

angiotropic lymphoma は，1959 年に Pfleger \& Tappeinerにより初めて報告され ${ }^{1)}$, 諸蔵器の 小血管腔内で増殖することから血管内皮由来の 
悪性腫瘍，neoplastic angioendotheliosis, NAE と診断されてきた。その後免疫染色の進歩の結 果，悪性リンパ腫の亜型であることが証明さ れ，そのほとんどは B リンパ球由来である。全 身の諸臓器の小血管内腔に腫瘍細胞が浸潤し, microangiopathy に基づく，中枢神経症状，皮膚 症状，呼吸不全，腎障害など様々な症状を呈す る。本邦では現在までに 200 例以上の報告があ $\eta^{2)}$ ，発症年齢は平均 $63 \pm 11$ 歳，平均罹病期 間は $8 \pm 8$ カ月である。男女差はない3)。

主に中年以降に亜急性の神経症状（特に意識 障害や痴呆) で発症し，画像上脳梗塞様の所見 を呈し, 血清 $\mathrm{LDH}$ 上昇や炎症所見を認めること が多いが，いずれも診断上特異的なものはな い。自験例でも診断確定の決め手となったのは 前胸部の毛細血管拡張部の病理組織所見であっ た。皮虐症状の出現率は $10 \%$ 前後と低く，生検 による診断率は約 3 分の 1 程度しかない4)。皮 膚症状は紅斑 - 紫紅色板状硬結 - 毛細血管桩 張・丘疹などがあり，血管塞栓のため網状皮斑 や潰瘍を呈することもある。自験例のようなク モ状血管腫様病変の発症機序は，化学療法開始 後に消退し可逆性であったことからも，皮膚の
微小血管が腫瘍細胞により閉塞されて起こる末 梢循環不全の代償反応と推測される。

治療としては，悪性リンパ腫に準じた化学療 法，放射線療法などが試みられているが短期間 の内に死亡する例も多い。本疾患では早期に診 断がつき治療が開始できれば，奏効する例も多 いことから，皮虐病変が認められれば積極的に 生検をし,診断をつけることが重要と思われた。

\section{文献}

1) Pfleger L, Tappeiner J : Zur Kenntnis der sistemisierten Endotheliomatose der cutanennBlutgefabe. Der Hauterzt, 10:359-363, 1959

2）村瀬卓平, 富田有三, 中村栄男：血管内大細胞性 B 細胞リンパ腫 (intravascular malignant lymphoma :ILV) の知見補遺-Asian variant of IVLを中心とす る文献的考察.臨床血液, 43:5-11, 2002

3）衛藤昌樹，豐岡圭子，小杉智ら：全身クモ状血管 腫様病変扔よび多彩な神経症状を呈した intravascular malignant lymphomatosis $の 1$ 剖検 例．臨床神経，41:107-112, 2001

4) 高尾昌樹, 厚東篤生, 岡部多加志：intravascular malignant lymphomatosis. 臨床神経, 43:391-407, 1995 